\title{
IMPLEMENTASI NILAI-NILAI PANCASILA PESERTA DIDIK DI MADRASAH IBTIDAIYAH MAMBAIL FALAH TONGAS- PROBOLINGGO
}

\author{
Nur Khosiah \\ STAI Muhammadiyah Probolinggo \\ nurkhosiah944@gmail.com
}

\begin{abstract}
ABSTRAK
Pendidikan merupakan suatu hal yang harus di dapat oleh setiap warga negara perkotaan sampai pelosok desa maupun pedalaman. Saat ini dalam manyambut era digitalisasi Indonesia harus sejak awal menanamkan nilai-nilai pancasila pada peserta didik agar faham tentang pancasila yang menjadi dasar negara kesatuan Republik Indonesia. Tujuan penelitian ini untuk mengetahui implementasi nilai-nilai pancasila pada paserta didik di MI Mambail Falah Tongas Probolinggo. Penelitian ini menggunakan metode penelitian kualitatif yaitu metode yang menekankan pada makna, penalaran, definisi tertentu, dan menggambarkan apa adanya mengenai obyek yang di teliti. Pada tehnik pengumpulan data yang digunakan adalah tehnik observasi, wawancara, dan dokumentasi. Adapun tehnik analisis data yang peneliti gunakan antara lain reduksi data yaitu pemilihan data yang penting, penyajian data yaitu merangkai beberapa data menjadi satu dan memilihnya sesuai denga yang di butuhkan, penarikan kesimpulan yaitu mengumpulkan bukti yang ada kemudian di deskripsikan secara cermat dan sistematis. Hasil penelitian ini menunjukkan bahwa Madrasah Ibtidaiyah Mambail Falah dalam mengiplementasikan nilai-nilai pancasila yaitu dengan melalui kegiatan pembelajaran agama, mata pelajaran Pkn dan mata pelajaran yang lainnya yaitu dengan mengajarkan dan menanamkan silasila pancasila dan pengimplementasinya dalam kegiatan di sekolah baik dalam kelas maupun di luar kelas.
\end{abstract}

Kata kunci: Implementasi Nilai-nilai pancasila, peserta didik 


\begin{abstract}
Education is something that must be obtained by every citizen of the city, villages and inland. At this time in welcoming era of digitalization Indonesia must implant the values of Pancasila for students so that they understand about Pancasila which is the basis of the unitary state of the Republic of Indonesia. The purpose of this study was to determine the implementation of Pancasila values from students in MI Mambail Falah Tongas Probolinggo. This research used qualitative research methods which are methods that emphasize the meaning, reasoning, definitions, and describe about the object being examined. The data collection techniques used are observation, interview, and documentation techniques. The data analysis techniques that researchers used include data reduction, namely the selection of important data, the presentation of data by assembling several data into one and selecting it according to what is needed, drawing conclusions, namely gathering existing evidence and then describing it carefully and systematically. The results of this study indicate that Madrasah Ibtidaiyah Mambail Falah in implementing Pancasila values is through religious learning activities, Pkn subjects and other subjects, exactly by teaching and instilling the precepts of Pancasila and their implementation in the school activities both in the classroom and outside the classroom.
\end{abstract}

Keywords: Implementation of Pancasila Values, students

\title{
PENDAHULUAN
}

Era digital saat ini, Perkembangan teknologi yang semakin maju dengan kecanggihannya telah menjadi bagian dari berbagai kegiatan manusia, baik dalam bidang perekonomian maupun bidang pendidikan dan tehnologi. Kebijakan baru yang inovatif dan strategis sangat diperlukan dalam berbagai segi kehidupan mulai dari sumber daya manusia, lembaga, mata pelajaran, pengembangan kurikulum yangkreatif dan inovatif ${ }^{1}$. Meski bangsa Indonessia pernah menjadi negara jajahan tapi jangan sampai nilai-nilai pancasila yang sudah di rumuskan oleh pendahulu kita yang sudah mempersatukan bangsa Indonesia, akan terabaikan begitu saja di hempas pengaruh zaman digital yang semakin berkemajuan. Meskipun tidak dapat kita pungkiri bahwa di era digital saat ini mempunyai dampak yang sangat signifikan dalam bidang kehidupan. Contohnya bidang pendidikan pelaksanaan ujian mulai dari kertas foto copyan sekarang sudah menggunakan laptob ataupun HP, penyimpanan data mulai dengan tumpukan kertas sehingga memakan tempat yang banyak sekarang sudah dapat di simpan di laptob ataupun HP,Pengiriman data guru

\footnotetext{
${ }^{1}$ Maemunah, 'Kebijakan Pendidikan Pada Era Revolusi Industri 4.0', Lembaga Penelitian Dan Pendidikan (LPP) Mandala, September, 2018, 1-9.
} 
maupun peserta didik sudah bukan lewat pos atau datang ke tempatnya akan tetapi sudah melalui email, HP, dan lain sebagainya.

Dari segi perekonomian contohnya dari sektor pertanian, membajak sawah dulunya menggunakan hewan (kerbau) akan tetapi sekarang sudah menggunakan mesin pembajak. Perubahan zaman yang semakin berkemajuan, membawa dampak nyata secara fisik contohnya pabrik, berupa polusi udara yang menyebabkan berbagai macam penyakit baru yang muncul yang sebelumnya belum ada penyakit seperti tumor, kanker dan lain sebagainya. Dampaknya terhadap gaya hidup, cara hidup, pola fikir yang lebih mengedepankan materi. Dampak lainnya secara psikologis dengan munculnya kebiasaan konsumtif yang berlebihan dan ketergantungan terhadap teknologi, seperti kebutuhan terhadap listrik, Hp, komputer, dan alat teknologi canggih lainnya ${ }^{2}$

Dalam menyambut era digital ini bangsa Indonesia harus melakukan terobosan baru dalam segala bidang, sebagai generasi muda bangsa Indonesia harus dapat mengisi era digital ini dengan maksimal sehingga generasi muda tidak pernah terprovokasi dengan mudah meski banyaknya arus dari luar yang mempengaruhi kehidupan bangsa ini asalkan kita tetap perpegang pada dasar negara kita yaitu Pancasila dan nilai-nilai yang terkandung dalamnya. Kita ajarkan para peserta didik kita sejak dari kanak-kanak sampai dewasa atau dari lembaga Kelompok Bermain sampai tingkat Perguruan Tinggi agar dari usia dini peserta didik kita faham benar apa itu pancasila dan dalam implementasinya sehari-hari.

Di era digitalisasi saat ini bangsa Indonesia harus mereformasi di bidang pendidikan, dengan menciptakan sistem yang relevan. Seperti yang kita lihat saat ini ada sedikit terjadi penurunan jiwa pancasila di kalangan peserta didik kita dan juga penurunan moralitas di kalangan pelajar maupun masyarakat pada umumnya contohnya banyaknya perkelahian antar pelajar,banyaknya kasus mencontek ketika ujian, minum-minuman keras di kalangan pelajar, peredaran narkoba yang semakin marak baik dikalangan pelajar maupun masyarakat, toleransi antar umat yang mulai memudar dan lain-lain. Maka dari itu peserta didik harus di tanamkan nilai-nilai pancasila di samping juga peran agama juga sangat mendukung dalam mengisi jiwa peserta didik menjadi pribadi mulya dan berjiwa pancasila. Pendidikan di Indonesia harus dirumuskan dan dirancang sebaik mungkin sehingga peserta didik dapat mengembangkan potensinya sesuai harapan dan sesuai dengan tujuan bangsa Indonesia tanpa mengurangi suasana kebebasan, tanggung jawab sebagai warga negara yang baik ${ }^{3}$

\footnotetext{
${ }^{2}$ Maemunah.

${ }^{3}$ Nur Hidayat, 'Peran Dan Tantangan Pendidikan Agama Islam Di Era Global', El-Tarbawi, 8.2 (2015), 131-45 <https://doi.org/10.20885/tarbawi.vol8.iss2.art2>.
} 
Sebagai bangsa yang berbhineka tunggal eka kita harus dapat menanamkan nilai-nilai Pancasila agar tetap terjaga samapai akhir nanti oleh karenanya sebagai generasi bangsa kita betul - betul harus menyiapkan diri agar dapat menghadapi dan dapat bersaing dalam segala bidang dalan menyongsong kehidupan yang berkemajuan tentunya dengan tetap membawa Indonesia menjadi lebih baik tanpa mengeyampingkan ciri khas bangsa Indonesia. Sementara itu nilai-nilai yang dikembangkan dalam pendidikan karakter bersumber dari: 1) Agama, 2) Pancasila, 3) Budaya, dan 4) Tujuan Pendidikan Nasional (Pusat Kurikulum, 2010).

Pancasila merupakan dasar sekaligus sebagai ideologi bangsa Indonesia menegakkan prinsip-prinsip kehidupan bernegara. Pancasila yang terdapat pada Pembukaan UUD 1945 dan diuraikan secara mendalam pada pasal-pasalnya yang Artinya, nilai-nilai dalam Pancasila menjadi nilai yang mengatur kehidupan berbangsa dan bernegara baik bidang, pendidikan, hukum, politik, ekonomi, seni budaya, dan kemasyarakatan. Pendidikan budaya dan karakter bangsa mempunyai tujuan mempersiapkan peserta didik menjadi warga negara yang baik, yaitu warga bermampuan, berkemauan, serta implementasi nilai-nilai Pancasila dalam kehidupan sebagai warga negara ${ }^{4}$

Bangsa ini membutuhkan generasi yang benar- benar mengamalkan Pancasila dalam kehidupan sehari-hari karena dapat dilihat dari hari kehari semakin nampak tanda- tanda surutnya nilai-nilai pancasila dalam kehidupan. Contohnya banyaknya perilaku kekerasan dimana-mana, di sekolah maupun masyarakat umum, pengaruh pergaulan/ peer group yang semakin merajalela di kalangan remaja dalam perilaku kekerasan, banyaknya remaja yang mengkonsumsi barang haram (minuman-minuman keras, narkoba, psikotropika dll), perilaku merusak diri (tato dsb), adab pada orang tua dan guru menurun, berkurangnya tanggungjawab pada setiap warga negara, adanya rasa saling curiga di antara sesama, mudah punya rasa iri dan dengki pada sesama sehingga tertanam benih kebencian, perilaku yang tidak jujur, makin kaburnya pedoman moral, etos kerja yang menurun. Era digitalisasi ini mempunyai pengaruh yang sangat luar biasa pada individu, keluarga, golongan, serta masyarakat pada umumnya.

Di era digital ini juga masih banyak sebagian warga negara Indonesia yang minim pengetahuan tentang Pancasila. Ini artinya sebagian warga negara mungkin belum banyak memperhatikan dan memahami nilai-nilai yang terkadung dalam pancasila. Ini ditemukannya warga negara yang tidak hafal sila pancasila kareana mungkin menganggap remeh sekolah, dan perasaan ingin menang sendiri tidak mengedepankan kepentingan umum, terjadinya degradasi moral di masyarakat.

\footnotetext{
${ }^{4}$ Sri Judiani, 'Implementasi Pendidikan Karakter Di Sekolah Dasar Melalui Penguatan Pelaksanaan Kurikulum', Jurnal Pendidikan Dan Kebudayaan, 16.9 (2010), 280 <https://doi.org/10.24832/jpnk.v16i9.519>.
} 
Melunturnya jiwa Pancasila dalam diri warga negara Indonesia ini tentuakan berakibat fatal dalam segi kehidupan bernegara dan juga akan mengancam keuutuhan dan keberlangsungan hidup bangsa, yang lebih mirisnya lagi Indonesia dapat terpecah keutuhannya, jika tidak ditanggulangi dengan baik tentu mengakibatkan masal serius bagi bangsa Indonesia dimasa mendatang ${ }^{5}$.

Dari beberapa uraian diatas kami tertarik untuk meneliti di Madrasah Ibtidauyah untuk mengetahui bagaimana penerapan nilai-nilai Pancasila di lakukan karena di zaman sekarang ini, Peserta didik banyak yang hafal sila-sila pancasila tapi penerapannya dalam kehidupan sehari-hari sudah mulai berkurang.

\section{METODE PENELITIAN}

\section{Jenis Penelitian}

Penelitian ini bertujuan untuk mendeskripsikan situasi pembelajaran di Madrasah Ibtidaiyah Mambail Falah Kecamatan Tongas Kabupaten Probolinggo yang telah menggunakan kurikulum 2013 dalam mengimplementasikan nilai-nilai pancasila pada peserta didik. Penelitian ini di lihat dari tempatnya merupakan penelitian lapangan yaitu penelitian yang menggunakan dan mengambil subyek yang diteliti. Pada penelitian yang dilakukan ini berjenis penelitian kualitatif, yaitu penelitian yang bertujuan untuk memahami beberapa gejala yang timbul pada anak dalam mengimplementasikan nilai-nilai pancasila, dan untuk menganalisis, mendeskripsikan, mencatat dan mengiterpretasikan keadaan nyata yang sedang terjadi ${ }^{6}$. Metode kualitatif ini lebih responsif dan mudah untuk penyesuaian dengan pola nilai-nilai yang dihadapi ${ }^{7}$

\section{Sumber data dan tehnik pengumpulan data}

Sumber data penelitian ini menggunakan sumber data primer yaitu sumber yang di dapat dari beberapa guru yaitu guru kelas I-VI di Madrasah Ibtidaiyah Mambail Falah. Dari sumber data tersebut peneliti menggali informasi yang berkaitan dengan proses pembelajarannya, metode yang diterapkan guru, situasi dan kondisi yang sedang berlangsung, sert kemampuan guru di Instasi tersebut.Data lainnya di dapat dari Kepala sekolah dan rekan kerja lainnya.

Peneliti melakukan penelitian ini antara bulan november 2019 sampai januari 2020 dan melakukan wawancara dengan kepala sekolah, guru kelas I-VI dan warga sekolah yang lainnya sehingga terkumpul informasi dan data awal mengenai

\footnotetext{
${ }^{5}$ Imron Wahyono, 'Implementasi Nilai-Nilai Pancasila Dalam Kegiatan Pembelajaran Di Sdn 1 Sekarsuli the Implementation of Pancasila ' $S$ Values in Learning Activities in Sdn 1', 2018.

${ }^{6}$ Khoirrosyid Oktifuadi, 'No Title No Title', Journal of Chemical Information and Modeling, 53.9 (2018), 1689-99 <https://doi.org/10.1017/CBO9781107415324.004>.

${ }^{7}$ Aziza Meria, 'Model Pembelajaran Agama Islam Bagi Anak Tunagrahita Di SDLB YPPLB Padang Sumatera Barat', 11.2 (2015), 355-80.
} 
implementasi nilai-nilai pancasila. Untuk pengumpulan data peneliti menggunakan beberapa tehnik antara lain observasi, wawancara, dan dokumentasi. Untuk mengumpulkan data, peneliti menggunakan beberapa teknik antara lain adalah wawancara, observasi dan dokumentasi.

Pertama observasi adalah mengumpulkan data dengan melalui pengamatan dan disertai denga mencatat setiap keadaan atau perilaku pada objek yang diteliti ${ }^{8}$. tehnik pengumpulan data melalui pengamatan dengan mencatat keadaan dan perilaku peserta didik dalam mengimplementasikan nilai-nilai pancasila di Madrasah Ibtidaiyah Mambail Falah. Pengumpulan data melalui observasi dilakukan dengan cara mengamati kondisi tempat penelitian yaitu madrasah Ibtidaiyah Mambail Falah Tongas Probolinggo, letak geografisnya, tata tertibnya, sarana prasaran, proses kegiatan implementasi nilai-nilai pancasila pada peserta didik di dalam kelas maupun di luar kelas dan didukung silabus, RPP.

Proses pengumpulan data yang kedua adalah wawancara yaitu teknik pengumpulan data dengan menggunakan cara tanya jawab dengan cara tersistematis sesuai denga tujuan ${ }^{9}$. Wawancara dilakukan dengan kepalah sekolah, guru kelas IVI dan sampel siswa kelas I-VI dari 140 siswa, warga sekolah lainnya untuk menggali informasi tentang implementasi nilai-nilai pancasila pada peserrta didik.

Tehnik pengumpulan data yang ketiga adalah dokumentasi yaitu suatu informasi yang diperoleh dengan bentuk gambar atau tulisan ${ }^{10}$ peneliti menggunakan tehnik dokumentasi ini untuk memperoleh data tambahan mengenai beberapa data tertulis maupun gambar yang ada di MI Mambail Falah Tongas Prbolinggo.

\section{Tehnik Analisis Data}

Tehnik analisis data yang di gunakan untuk mendapatkan kesimpulan dan jawaban yang sistematis maka data dari hasil observasi, wawancara dan dokumentasi dilakukan dengan mengumpulkan data ke dalam kategori, langkahlangkah sebagai berikut:

a. Reduksi data

Peneliti melakukan pemilihan hal penting dan pokok, selanjutnya dibuat kategori dan memilih data yang penting ${ }^{11}$. Dalam reduksi data ini merupakan pemilihan hal penting dan pokok sehingga dapat memudahkan peneliti mengumpulkan data yang berkenaan dengan implementasi nilai-nilai pancasila di lingkungan Madrasah.

b. Penyajian Data

\footnotetext{
${ }^{8}$ Oktifuadi.

${ }^{9}$ Meria.

${ }^{10}$ Meria.

${ }^{11}$ (Sugiyono, 2008)
} 
Penyajian data yaitu merangkai beberapa data dalam satu informasi, sehingga mudah untuk menyimpulkan, dan mudah difahami ${ }^{12}$.Penyajian data yang dimaksud adalah memilih data sesuai dengan apa yang di butuhkan tentang implementasi nilai-nilai pancasila di Madrasah Ibtidaiyah Mambail falah.

c. Penarikan Kesimpulan

Penarikan kesimpulan yang dilakukan peneliti yaaitu dengan mengumpulkan beberapa bukti penelitian di lapangan. Selanjutnya peneliti melakukan deskripsi data yang telah diperoleh dan di analisis secara cermat dan sistematis.

\section{IMPLEMENTASI PENANAMAN NILAI-NILAI PANCASILA}

Dasar negara, ideologi dan pandangan hidup bangsa Indonesia adalah Pancasila maka harus ditanamkan dimulai dari sekolah Kelompok Bermain sampai sekolah tingkat perguruan tinggi, di tiap sekolah Pancasila wajib di kenalkan, di ajarkan, di tanamkan pada semua peserta didik dan juga anggota masyarakat. Banyak sekalipengaruhnya bagi peserta didik di era digital ini, bukan saja pengaruh positif akan tetapi pengaruh negatif juga tidak dapat kita hindari begitu saja, apalagi peserta didik saat ini rasa keingintahuannya lebih kuat dari pada peserta didik di tahun-tahun sebelumnya.Untuk itu di perlukan bentuk kerjasama yang saling menguntungkan antara pihak sekolah dengan orang tua agar penyatuan visi, misi dan harapan sekolah serta orang tua ke depannya menjadi generasi yang patut di banggakan dan menjadi kebanggaan bangsa Indonesia.

Permasalahan yang dihadapi akhir-akhir ini sangat komplek sekali yaitu dari dalam negeri ada pihak yang memprovokasi sekelompok orang yang ingin keluar dari KesatuanNegara Republik Indonesia, ini berarti mulai melunturnya sikap cinta tanah air, menurunnya moralitas anak yang terjadi dalam kehidupan seharihari,menurun juga rasa persatuan dan kesatuan bangsa, ini mencerminkan kurangnya pengetahuan dan pengamalan niali-nilai pancasila sehingga apa yang menjadi tujuan bangsa Indonesia belum seutuhnya terpenuhi dan tercapai. ${ }^{13}$. Penanaman nilai-nilai Pancasila ini harusnya sudah terukir pada jiwa semua warga negara Indonesia agar apa yang menjadi harapan dan tujuan mulia bangsa Indonesia tercapai dan perjuangan pendahulu kita tidak sia-sia dalam merebut kemerdekaan dari tangan penjajah serta merumuskan pancasila sesuai dengan hati nurani rakyat karena melihat bangsa Indonesia yang memiliki kemajemukan dari berbagai budaya, bahasa, suku, adat, kearifan lokal dan agama agar antara yang satu dengan yang lainnya tidak terpecah belah sehingga bangsa Indonesia menjadi satu kesatuan yang utuh.

12 Oktifuadi.

13 Ambiro Puji Asmaroini, 'Implementasi Nilai-Nilai Pancasila Bagi Siswa Di Era Globalisasi', Citizenship Jurnal Pancasila Dan Kewarganegaraan, 4.2 (2016), 440 <https://doi.org/10.25273/citizenship.v4i2.1077>. 
Implementasi nilai-nilai Pancasila pada peserta didik penting sekali untuk ditanamkan dan diterapkan dalam kesehariannya. Menurut apa di ungkapkan oleh kalidjernih bahwa Penanaman nilai-nilai Pancasila yang diterapkan pada sekolah dasar masuk dalam setiap proses pembelajaran (psyco- pedagogial development) disebabkan prosespembelajaran yang dilaksanakan pada setiap sekolah dasar tidak mengandung tiga rana antara lain: rana kognitif, afektif dan psikomotor ${ }^{14}$. Jadi para pendidik atau guru dalam menyampaikan materi pembelajarannya menerapkan berbagai metode pembelajaran, agar tercipta proses pembelajaran yang menyenangkan baik itu di kelas maupun di luar kelas.

Di Madrasah Ibtidaiyah Mambail Falah desa Tanjungrejo Kecamatan Tongas Kabupaten Probolinggo ini dalam mengiplementasikan Nilai-nilai Pancasila antara lain Melalui kegiatan pembelajaran agama, mata pelajaran Pkn dan mata pelajaran yang lainnya yaitu dengan mengajarkan dan menanamkan sila-sila pancasila yang jumlahnya ada 5 dan pengimplementasinya dalam kegiatan di sekolah yaitu "Ketuhanan Yang Maha Esa". Dari sejak nenek moyang kita terdahulu masyarakat Indonesia sudah percaya kepada Tuhan. Sila pertama inilah yang menjiwai keempat sila lainnya. Sebagaimana yang di ungkapkan oleh Notonagara(1975:23) dalam kaelan (2014:56) bahwasannya Pendukung kelima sila dalam Pancasila adalah manusia, sebagaimana dalam penjelasannya dan butir-butir yang telah disebutkan sila pertama Ketuhanan yang Maha Esa, sila kedua Kemanusiaan yang adil dan beradab, sila ketiga Persatuan Indonesia, sila keempat Kerakyatan yang dipimpin oleh hikmat kebijaksanaan dalam permusyawaratan dan perwakilan, sila kelima Keadilan sosial bagi seluruh rakyat Indonesia pada hakekatnya yang menjalankan semua adalah manusia.

Diantara cara yang diterapkan pada Madrasah Ibtidaiyah Mambail Falah ini dalam mengimplementasikan nilai-nilai Pancasila sila pertama Ketuhanan yang Maha Esa dengan beberapa pembiasaan diantaranya dengan 5S (senyum, salam, sapa,sopan,santun), berdoa sebelum dan setelah pembelajaran, pembacaan surahsurah pendekdi halaman sekolah sebelum masuk kelas masing-masing, sholat dhuha dan sholat dhuhur yang dilaksanakan secara berjamaah. Hal ini memperlihatkan di antara peserta didik dalamkerja sama dan toleransi sangat baik, terbukti antar peserta didiksaling mengingatkan dalam hal kebaikan, sehingga dengan sendirinya ke mushollah tanpa di minta oleh guru. Saat selesai sholat ada dzikir bersama dan doa bersama yang dipimpin oleh guru dan dalam pengawasan guru pula agar dalam kegiatan berjalan dengan tertib.

Menurut Notonagara (1975) dalam Kaelan (2014: 58) bahwa sila kedua Kemanusiaan Yang Adil dan Beradab dijiwai oleh sila-sila yang lain, Negara

14 Freddy K Kalidjernih, 'Jurnal Civics: Media Kajian Kewarganegaraan Terhadap Revitalisasi Pancasila’, 16.1 (2019), 103-10. 
merupakan lembaga kemanusiaan yang diadakan oleh manusia. Keadilan yang ingin dicapai dalam hidup manusia bersama sebagai mahluk Tuhan yaitu mewujudkan keadilan dalam hidup yang saling berdampingan. Sebagai makhluk Tuhan Yang Maha Esa sesama manusia harus saling menghargai, menjunjung tinggi hak, persamaan derajat tanpa membedakan status dan golongandari mana dia berasal karena Indonesia adalah satu. Implementasi nilai-nilai Pancasila sila keduayang dilaksanakan di Madrasah Ibtidaiyah Mambail Falah dengan membiasakan budaya 5S (senyum, salam, sapa, sopan, santun), menghormati yang lebih tua dan menyayangi yang lebih muda. Guru memberikan ketauladanan dan adil pada setiap peserta didik contohnya tidak membedakan si kaya dan si miskin, ras, bahasa, tempat tinggal, jenis kelamin, fisik dalam proses pembelajaran, apabila bertemu di jalan membiasakan bersalaman/ menyapa, melaksanakan tugas kelompok,serta menjenguk teman yang sedang sakit.

Menurut Kaelan (2014: 59) menyatakan bahwa hakikat sila ketiga Persatuan Indonesia dijelaskan bahwa yang mendasari sila ketiga ini adalah sila Ketuhanan Yang Maha Esadan Kemanusian, bahwasannya manusia sebagai makhluk ciptaan Tuhan yang harus merealisasikan terwujudnya suatu persatuan dalam hidup bermasyarakat. Tanpa memandang status, perbedaan warna kulit, keturunan, suku, agama serta dapat menumbuhkan rasa cinta tanah air.Implementasi nilai-nilai Pancasila sila ketiga di MI Mambail Falah ini dengan berbagai cara yaitu dengan penanaman rasa kecintaan pada Negara dan tanah air Indonesiacontohnya melaksanakanupacara bendera dengan disiplin dan tertib setiap hari senin, menyanyikan lagu kebangsaan Indonesia Raya, membaca teks Pancasila sebelum pelajaran di mulai, datang tepat waktu, dengan mengadakan piket kelas berkelompok, out bond sekolah, menjaga kebersihan lingkungan, merawat tanaman di sekolah, membuang sampah pada tempatnya. Contoh yang lain dalam menerapkan nilai persatuan dengan sholat berjamaah sholat duha, sholat dhuhur, yang dapat menjadikan antar siswa saling mengingatkan dan lebih akrab dalam dalam kesehariannya.

Dalam Kelan (2014:59) menyatakan bahwa dalam sila keempat kerakyatan yang dipimpim oleh hikmat kebijaksanaan dalam permusyawaratan/perwakilan, maka sila keempat ini mengandung pokok kerakyatan yang kesemuanya di tujukan untuk rakyat. Permusyawaratan artinya musyawarah untuk mufakat, setelah itu diadakandan dilaksanakan bersama. Implementasi nilai-nilai Pancasila sila keempat ini yang dilakukan di MI Mambail Falah yaitu pertama membimbing dan mengarahkan adanya susunan kepengurusan kelas/ struktur kelas melalui musyarawarah kelas,Membiasakan menyelesaikan suatu permasalahan di kelas dengan jalan musyawarah mufakat, kebebasan dalam menyampaikan pendapat tanpa memandang keturunan, kaya atau miskin, agama dan lain-lain.Mengikuti kegiatan extra contoh: pramuka dan mengadakan perkemahan di sekolah agar 
peserta didik lebih akrab tanpa memandang perbedaan yang ada. Extra drum band dan banjari agar kerja sama dan kekompakan semakin terjalin dengan baik.

Menurut notonagaro (1975:141) dalam kaelan (2014:60) bahwasannya sila Keadilan sosial bagi seluruh rakyat Indonesiaini adalah tujuan dari sila pertama sampai sila keempat.maka sila kelima ini didasari pada sila ketuhanan, kemanusiaan,persatuan,dan kerakyatan. Adapunpokok pikirannya kesejahteraan dan kemakmuran bagi rakyat Indonesia, kekayaan alam seluruhnya untuk kepentingan umum dan kesejahteraan bersama, serta melindungi seluruh masyarakat agar dapat bekerja sesuai bidang keahliannya. Implementasi nilai-nilai sila kelima di MI Mambail Falah yaitu dengan cara bebas menyampaikan pendapat baik dalam proses pembelajaran maupun kegiatan di luar kelas, bersikap adil, toleransi antar teman tanpa memandang perbedaan. Peserta didik di ajarkan berbagi dengan temannya misalkan punya jajan ada teman yang minta jajannya ini berbagi, kegiatan menggambar membagi pewarnanya, bermain bersama misalkan ada peserta didik lain punya mainan baru.

Implementasi nilai-nilai pancasila di sekolah hendaknya diterapkan sejak usia kanak-kanak karena di era digital saat ini jika tidak di tanamkan dari masa kanak-kanak akan berpengaruh ketika sudah beranjak remaja dan dewasa. Maka setiap sekolah di harapkan dengan sungguh-sungguh mengimplementasikan nilainilai pancasila sesuai dengan Undang-Undang no 20 tahun 2003 pasal 2 yaitu pendidikan pancasila dan UUD 1945. Adapun cara yang di terapkan seorang guru dalam mengimplemetasikan nilai-nilai pancasila di sekolah dengan menggunakan berbagai pendekatan, metode dan model pembelajaran dalam kelas, di luar kelas maupun lingkungan sekitar.

Dalam Peraturan Menteri Pendidikan Nasional Nomor 23 Tahun 2006 tentang Standar Kompetensi Lulusan menyatakan bahwasannyatujuan pendidikan dasar yaitu meletakkan dasar akhlak yang mulia, berkepribadian, pengetahuan, kecerdasan, serta keterampilan agar dalam menjalani hidup lebih terarah, mandiri dan berpendidikan tinggi. ${ }^{15}$. Untuk itulah para peserta didik kita harus menguasai dan menerapkan nilai-nilai pancasila sebab pancasila sebagai sumber pengetahuan dari bangsa kita sendiri bukan dari bangsa lain.

Warga negara yang baik adalah yang mampu mengenali jati dirinya sebagai bangsa Indonesia, bangsa yang besar, yang sudah mendapat pengakuan dari bangsabangsa lain diseluruh dunia, penerapan nilai-nilai Pancasila harus terlihat dalam suatu peraturan baik tingkat daerah, provinsi, pusat,dan juga dalam perundangundangannya yang berlaku di Indonesia. Pancasila harus terwujud nyata dalam suatu peraturan, perundang-undangan dan dapat mengarahkan masyarakat untuk bersikap

\footnotetext{
${ }^{15}$ Judiani.
} 
dan berperilaku sesuai dengan peraturanyang berlaku, perundangan pusat ,kebijakan yang disesuaikan dengan Pancasila ${ }^{16}$

\section{IMPLEMENTASI NILAI-NILAI PANCASILA DALAM KEGIATAN SOSIAL}

Dasar negara Indonesiaadalah Pancasila yang menjadi pedoman, pondasi, kaidah hukum yang mengatur dan menyelenggarakan. Andaikata negara menjadi bangunan,maka pancasila adalah fondasinya yang akan menjadi pijakan. Dalam pembuatan peraturan, kebijakan, dan perundang-undangan bangsa Indonesia yang kita cintai ini, Pancasila menjadi dasar dan pondasinya. Dan berbagai peraturan di Indonesia, semua berpijak pada pancasila baik dalam bidang sosial, politik,pendidikan, budaya, pendidikan maupun pertahanan dan keamanan. Pancasila berisikan nilai-nilai luhur yang sesuai dengan kondisi masyarakat Indonesia. Sebagaimana yang diungkapkan hidayat bahwasannya Pancasila memiliki nilai kebudayaan yang dijadikan pondasi dan dasar dalam suatu kegiatan ataupun proses pendidikan yang multicultural ${ }^{17}$ belum

Dalam Pancasila mengandung berbagai nilai-nilai pengajaran mulia, yang didalamnya mengandung kearifan lokal kedaerahan, kebudayaan, suku, adat dan agama di Indonesia. Untuk melestarikannya dan menerima nilai-nilai yang diyakini oleh masyarakat pengikutnya, menentukan baik dan buruknya, pantas dan tidaknya dengan melalui proses menimbang. Dan dalam masyarakat Indonesia mempunyai perbedaan yang sangat menonjol baik dari segi agama, bahasa, adat, suku, kebudayaan, sehingga tidak heran jika masyarakat Indonesia terdapat banyak sekali perbedaan tentang tata nilai yang terdapat dalam masyarakat, dan juga nilai sosial dapat diidentifikasi denga memperhatikan berdasarkan nilai sosial (Sosial: 2013)

Implementasi dalam kehidupan sosial masyarakat tentang nilai-nilai pancasila sangat dibutuhkan, karena menerapkan nilai-nilai pancasila akan berpengaruh pada pola pikir masyarakat dan acuhan bagaimana sejatinya pancasila sebagai dasar negara itu bukan dari hasil pemikiran orang lain ataupun bangsa lain akan tetapi pancasila adalah murni dari pandangan, jiwa ,ideologi bangsa kita sendiri yaitu bangsa Indonesia. Contoh penerapan nilai-nilai pancasila dalam sosial dalam masyarakat antara lain bersih desa, dengan adanya bersih desa ini peserta didik kita akan melihat, mempraktekkan, mengamalkan sila-sila dalam pancasila yang telah diberikan dan di contohkan oleh bapak/ibu guru di sekolah apalagi melihat kekompakan masyarakat tentu mereka akan semakin bangsa menjadi bangsa Indonesia dimanapun mereka berada. Contoh lain slametan desa ini menunjukkan

\footnotetext{
${ }^{16}$ Hidayat.

${ }^{17}$ Dewi Oktaviani Hidayat and others, 'Implementasi Nilai-Nilai Pancasila Dalam Mencegah Degradasi Moral Terhadap Isu Sara Dan Hoax’, Jurnal Rontal Keilmuan PKN, 1945.
} 
masyarakat Indonesia yang mempunyai budaya dan kearifan lokal sendiri yang tentunya akan memperkuat silaturahmi dan menciptakan kerukunan sesama warga desa khusunya dan masyarakat Indonesia pada umumnya.

Implementasi nilai sosial dalam masyarakatmerupakan suatu sistem pengatur kegiatan individu yang terdapat di masyarakat. Tentunyadalam komunitas masyarakat memiliki kearifan lokal tersendiri yang memiliki budayaayangberbeda dengan masyarakat lainnya. Di atas sudah disebutkan contoh lain adalah mencium tangan/ bersalaman dengan orang yang lebih tua di masyarakatsudah menjadi kebiasaan dan umum dilakukan akan menjadikan anak yang beradab. Penerapan ilmu yang telah di dapatkannya, dan terdapat nilai-nilai tertentu sehinggadapat membantu keberhasilan seseorang sebagaianggotamasyarakat dalam hal kedudukannya dalamstruktur sosialdimanapun keberadaannya baik secara lahir maupun bathinnya. ${ }^{18}$

Dengan demikian implementasi nilai-nilai pancasila penting sekali dalam masyarakat, lembaga pendidikan dalam meningkatkan pengetahuan dan pemahaman tentang ideologi pancasila, mengamalkan nilai-nilai pancasila bukan saja di lembaga/ sekolah akan tetapi dalam masyarakat, karena di dalam pancasilasudah terkandung nilai-nilai luhur sesuai dengan jati diri bangsa Indonesia,membentuk pola pikir peserta didik agar tidak terjerumus ke dalam ideologi bangsa lain sebab di era kekinian atau era digitalisasi ini apa yang kita ingin lihat dapat di akses dengan mudah melalui internet dengan HP, laptob dsb jika peserta didik dan masyarakat tidak mengerti nilai-nilai dalam pancasila, tentunya mudah terpengaruh dengan era yang semakin berkemajuan ini dan bukan tidak mungkin jika paserta didik dan masyarakat tidak mengetahui dan menerapkan nilainilai pancasila apalah jadinya bangsa Indonesia ini. ${ }^{19}$

\section{PROBLEMATIKA PENANAMAN NILAI-NILAI PANCASILA}

Kehidupan berbangsa dan bernegara tentu akan ada berbagai persoalan yang akan terjadi dalam menjalani kehidupan berbangsa dan bernegara, karena semua bangsa pasti akan mengalaminya sebab itu sudah merupakan takdir dari Sang Pencipta. Bangsa yang besaradalah bangsa harus siap menyambut dan menjalani semua persoalan dan tantangan zaman di era kemajuan ini. Untuk itu kita harus mempersiapkan peserta didik kita sejak awal agar kokoh dengan pendiriannya sebagai masyarakat Indonesia yang penuh dengan adat ketimuran nya, yang terkenal dengan keramah- tamahannya dan kita harus melestarikan warisan leluhur bangsa Indonesia. Kita harus siap dengan kemajuan zaman yang ada tentunya dengan berbagai cara agar tidak menjadi bangsa yang masyarakatnya suka mengadopsi

\footnotetext{
${ }^{18}$ Wahyono.

${ }^{19}$ Oktaviani Hidayat and others.
} 
sesuatupun dari negara lain. Salah satu caranya dengan mengimplementasikan nilainilai pancasila dalam bermasyarakat dan bernegara.

Faktor pendukung implementasi nilai-nilai Pancasila di MI Mambail Falah Tanjungrejo Kecamatan Tongas Kabupaten Probolinggo adalah datang dari berbagai pihak antara lain Cabang dinas Pendidikan, kepala sekolah,warga sekolah, guru, dan lingkungan sekolah. Dinas Pendidikan dan Kepala Sekolahselalu menberikan dukungan kepada pihak sekolah, progam sekolah, kebijakan sekolah, dalam pengamalan nilai-nilai Pancasila yang benar. Warga sekolah yang lain juga harus selalu memberikan berbagai metode dan ketalaudanan pada peserta didik supaya penanaman nilai-nilai pancasila berjalan dengan lancar dan baik. Daripemerintah pusat memogramkan dan menekankan pendidikan karakter pada setiap jenjang pendidikan yang dituangkan dalam setiap proses pembelajaran terutama pada pendidikan agama dan Pendidika pancasila dan kewarganegaraan.

Adapun cara Kepala Sekolah dalam mendukung implementasi nilai-nilai Pancasila yaitu dengan mengambil kebijakan mengadakan kegiatan keagamaan dan pengembangan ekstrakurikuler. Cabang dinas pendidikan setempat memantau dan memberi arahan pada sekolah. Guru pelaksana di lapangan selalu memberikan ketauladanan kepada peserta didik baik di sekolah maupun di masyarakat. Seorang guru membimbing dan menanamkan nilai-nilai Pancasila dalam segala aktivitas di sekolah,Guru membangun dan mengembangkan kreatifitas siswa yang berhubungan dengan nilai-nilai luhur Pancasila baik dalam aktivitas proses pembelajaran maupun yang aktivitas yang lain. Lingkungan sekolah dan masyarakat sekitar memberikan dukungan penuh pada sekolah yang menerapkan nilai pancasila dalam kesehariannya. Warga sekolah terutama guru memaksimalkan lingkungan yang ada dalam menerapkan nilai-nilai pancasila seperti cinta lingkungan dengan membuang sampah pada tempatnya, menyiram taman, menanam bunga, merawat bunga dan melestarikan kegiatan yang positif, mengenalkan dan mempraktekkan permainan tradisional di saat prosese pembelajaran berlangsung yang sesuai dengan materi dan saat berolah raga. Semua warga sekolah memanfaatkan fasilitas lingkungan sekitar sekolah antara lain masjid, koperasi siswa, perpustakaan, tempat mainan, taman, dan fasilitas lainnya.

Kita bangsa Indonesia sudah merdeka selama tujuh puluh empat tahun, dari tahun ke tahun perubahan zaman semakin terasa. Kehidupan di era sekarang yang banyak orang menyebutnya era, tentu berbagai tantangan yang kita hadapi dari segala bidang kehidupan mulai dari ekonomi, politik, sosial, budaya, dan masih banyak lainnya yang harus perbaiki dan majukan agar tidak tertinggal dengan bangsa lain, akan tetapi tetap perpegang pada nilai-nilai luhur bangsa Indonesia.Pertama, nilai-nilai Pancasila sepertinya mulai kurang mendapat perhatikan dari sebagain generasi muda, belum diterapkan dengan baik oleh masyarakat nilai yang terkandung dalam pancasila, Pancasila seolah dijadikan 
simbol, tanpa penerapan nyata dalamkehidupan sehari-hari dalam masyarakat maupun kehidupan tataran bernegara. Kedua, generasi muda dan masyarakat Indonesia pada umumnya sudah banyak terpengaruh dengan dunia luar dan budaya luar yang memasuki Indonesia, sehingga mulai menjamurnya perilaku dan sikap yang tidak sesuai dengan nilai-nilai Pancasila.Ketiga, nilai-nilai patriotisme sudah mulai memudar.

Adapun problematika dalam implementasi nilai-nilai Pancasila di sekolah antara lain apabila lingkungn masyarakat, lingkungan keluarga maupun lingkungan tempat tinggal anak di rumah kurang mendukung dan kurang membimbing serta kurang memberikan contoh yang baik tentu penanaman nilai-nilai pancasila sulit diterapkan. Warga sekolah sudah berusaha maksimal membiasakan dan memberikan sertamenanamkan nilai-nilai Pancasila di lingkungan sekolah namun jikalau anak di rumah, lingkungan keluarga dan masyarakat kurang mendapatkan contoh yang baik, tentu hal ini akan berpengaruh pada anak berkaitan dengan keberhasilan penanaman nilai-nilai Pancasila. Karena banyak sekali faktor dapat memengaruhi perkembangan anak antar lain; polah asuh orang tua, perhatian dan kasih sayang orang tua dan lain sebagainya. Seorang anak dapat terbentuk karakternya dan tertanam nilai-nilai pancasila dapat dipengaruhi oleh pembiasaan yang di trapkan dalam keluarganya dan lingkungan tempat tinggalnya.

Upaya Madrasah Ibtidaiyah Mambail Falah tanjungrejo kecamatan tongas Kabupaten Probolinggo dalam mengatasi hambatan dalam penanaman nilai-nilai Pancasila yaitu dengan melakukan pembiasaan di MI Mambail Falah, mendisiplinkan dan mengingatkan pada peserta didik kegiatan di sekolah dan selalu mengadakanpembinaan serta bekerja sama dengan wali murid agar memberikan dukungan, bimbingan dan arahan kepada putra dan putri mereka.

\section{KESIMPULAN}

Bangsa Indonesia harus mereformasi segala bidang terutama di bidang pendidikan sebab pendidikan yang akan membawa generasi Indonesia menjadi generasi maju. Dengan merancang sistem pendidikan inovatif, efektif dan fleksibel, sehingga para lulusan dapat berinovasi sendiri dan berfungsi dengan baik dalam kehidupan keluarga, masyarakat,serta lingkunga dimanapun dia menempatkan dirinya.Sebagai bangsa yang berbhineka tunggal eka kita harus dapat menanamkan nilai-nilai Pancasila agar tetap terjaga sampai akhir nanti oleh karenanya sebagai generasi bangsa kita betul - betul harus menyiapkan diri agar dapat menghadapi dan dapat bersaing dalam segala bidang dalan menyongsong kehidupan yang berkemajuan tentunya dengan tetap menjadikan bangsa Indonesia sebagai bangsa yang lebih baik dan berkemajuan tanpa mengeyampingkan ciri khas bangsa Indonesia. 
Untuk itu dari segi pendidikan mempunyai peranan yang penting dalam menanamkan nilai-nilai pancasila karena tidak mungkin dalam suatu keluarga akan memberikan pelajaran yang ada di sekolah utamanya pancasila sehingga nilai-nilai luhur yang terkandung dalam pancasila akan tertanam dalam diri peserta didik tanpa perantara dari tempat mereka mendapatkan ilmu pendidikan dan pelajaran yang sesuai dengan harapan yaitu sekolah.Pancasila sebagai ideologi negara, pandangan hidup dasar negara bangasa Indonesia harus ditanamkan dimulai dari sekolah Kelompok Bermain sampai sekolah tingkat perguruan tinggi, di tiap sekolah Pancasila wajib di kenalkan, di ajarkan, di tanamkan pada semua peserta didik dan juga anggota masyarakat.

Di Madrasah Ibtidaiyah Mambail Falah desa Tanjungrejo Kecamatan Tongas Kabupaten Probolinggo ini dalam mengiplementasikan Nilai-nilai Pancasila antara lain Melalui kegiatan pembelajaran agama, mata pelajaran Pkn dan mata pelajaran yang lainnya yaitu dengan mengajarkan dan menanamkan sila-sila pancasila yang jumlahnya ada 5 dan pengimplementasinya dalam kegiatan di sekolah. Penanaman dan penerapan nilai-nilai pancasila dalam kehidupan bermasyarakat sangat dibutuhkan, karena menerapkan nilai-nilai pancasila akan berpengaruh pada pola pikir masyarakat dan acuhan bagaimana sejatinya pancasila sebagai dasar negara itu bukan dari hasil pemikiran orang lain ataupun bangsa lain akan tetapi pancasila adalah murni dari pandangan, jiwa ,ideologi bangsa kita sendiri yaitu bangsa Indonesia.

Faktor pendukung implementasi nilai-nilai Pancasila di MI Mambail Falah Tanjungrejo Kecamatan Tongas Kabupaten Probolinggo adalah datang dari berbagai pihak antara lain Cabang dinas Pendidikan, kepala sekolah, warga sekolah, guru, dan lingkungan sekolah. Dinas Pendidikan dan Kepala Sekolahselalu menberikan dukungan kepada pihak sekolah, progam sekolah, kebijakan sekolah, dalam pengamalan nilai-nilai Pancasila yang benar. Warga sekolah yang lain juga harus selalu memberikan berbagai metode dan ketalaudanan pada peserta didik supaya penanaman nilai-nilai pancasila berjalan dengan lancar dan baik. Dari pemerintah pusat memogramkan dan menekankan pendidikan karakter pada setiap jenjang pendidikan yang dituangkan dalam setiap proses pembelajaran terutama pada pendidikan agama dan Pendidikan pancasila dan kewarganegaraan.

Adapun problematika dalam implementasi nilai-nilai Pancasila di sekolah antara lain apabila lingkungn masyarakat, lingkungan keluarga maupun lingkungan tempat tinggal anak di rumah kurang mendukung dan kurang membimbing serta kurang memberikan contoh yang baik tentu penanaman nilai-nilai pancasila sulit diterapkan. Warga sekolah sudah berusaha maksimal membiasakan dan memberikan serta menanamkan nilai-nilai Pancasila di lingkungan sekolah namun jikalau anak di rumah, lingkungan keluarga dan masyarakat kurang mendapatkan 
contoh yang baik, tentu hal ini akan berpengaruh pada anak berkaitan dengan keberhasilan penanaman nilai-nilai Pancasila

Upaya Madrasah Ibtidaiyah Mambail Falah tanjungrejo kecamatan tongas Kabupaten Probolinggo dalam mengatasi hambatan dalam penanaman nilai-nilai Pancasila yaitu dengan melakukan pembiasaan di MI Mambail Falah, mendisiplinkan dan mengingatkan pada peserta didik kegiatan di sekolah dan selalu mengadakan pembinaan serta bekerja sama dengan wali murid agar memberikan dukungan, bimbingan dan arahan kepada putra dan putri mereka.

\section{DAFTAR PUSTAKA}

Asmaroini, Ambiro Puji, 'Implementasi Nilai-Nilai Pancasila Bagi Siswa Di Era Globalisasi', Citizenship Jurnal Pancasila Dan Kewarganegaraan, 4.2 (2016), 440 <https://doi.org/10.25273/citizenship.v4i2.1077>

Hidayat, Nur, 'Peran Dan Tantangan Pendidikan Agama Islam Di Era Global', El-
Tarbawi,
8.2
(2015),
131-45

<https://doi.org/10.20885/tarbawi.vol8.iss2.art2>

Judiani, Sri, 'Implementasi Pendidikan Karakter Di Sekolah Dasar Melalui Penguatan Pelaksanaan Kurikulum', Jurnal Pendidikan Dan Kebudayaan, 16.9 (2010), 280 <https://doi.org/10.24832/jpnk.v16i9.519>

Kalidjernih, Freddy K, 'Jurnal Civics : Media Kajian Kewarganegaraan Terhadap Revitalisasi Pancasila', 16.1 (2019), 103-10

Mufaizin. "Metode Pendidikan Islam Perspektif Hadits." Edupedia 3.1 (2018): 55 66.

Maemunah, 'Kebijakan Pendidikan Pada Era Revolusi Industri 4.0', Lembaga Penelitian Dan Pendidikan (LPP) Mandala, September, 2018, 1-9

Meria, Aziza, 'Model Pembelajaran Agama Islam Bagi Anak Tunagrahita Di SDLB YPPLB Padang Sumatera Barat', 11.2 (2015), 355-80

Oktaviani Hidayat, Dewi, Inggi Eltariant, Rahmat Kevin Priyatna, and Sindi Agustina Fernanda, 'Implementasi Nilai-Nilai Pancasila Dalam Mencegah Degradasi Moral Terhadap Isu Sara Dan Hoax', Jurnal Rontal Keilmuan PKN, 1945

Oktifuadi, Khoirrosyid, 'No Title No Title', Journal of Chemical Information and Modeling, $\quad 53.9 \quad$ (2018), 1689-99 <https://doi.org/10.1017/CBO9781107415324.004>

Wahyono, Imron, 'Implementasi Nilai-Nilai Pancasila Dalam Kegiatan 
Pembelajaran Di Sdn 1 Sekarsuli the Implementation of Pancasila' S Values in Learning Activities in Sdn 1', 2018

Asmaroini, Ambiro Puji, 'Implementasi Nilai-Nilai Pancasila Bagi Siswa Di Era Globalisasi', Citizenship Jurnal Pancasila Dan Kewarganegaraan, 4.2 (2016), 440 <https://doi.org/10.25273/citizenship.v4i2.1077>

Hidayat, Nur, 'Peran Dan Tantangan Pendidikan Agama Islam Di Era Global', El-
Tarbawi, 8.2
(2015),
$131-45$

<https://doi.org/10.20885/tarbawi.vol8.iss2.art2>

Judiani, Sri, 'Implementasi Pendidikan Karakter Di Sekolah Dasar Melalui Penguatan Pelaksanaan Kurikulum', Jurnal Pendidikan Dan Kebudayaan, 16.9 (2010), 280 <https://doi.org/10.24832/jpnk.v16i9.519>

Kalidjernih, Freddy K, 'Jurnal Civics : Media Kajian Kewarganegaraan Terhadap Revitalisasi Pancasila', 16.1 (2019), 103-10

Maemunah, 'Kebijakan Pendidikan Pada Era Revolusi Industri 4.0', Lembaga Penelitian Dan Pendidikan (LPP) Mandala, September, 2018, 1-9

Meria, Aziza, 'Model Pembelajaran Agama Islam Bagi Anak Tunagrahita Di SDLB YPPLB Padang Sumatera Barat', 11.2 (2015), 355-80

Oktaviani Hidayat, Dewi, Inggi Eltariant, Rahmat Kevin Priyatna, and Sindi Agustina Fernanda, 'Implementasi Nilai-Nilai Pancasila Dalam Mencegah Degradasi Moral Terhadap Isu Sara Dan Hoax', Jurnal Rontal Keilmuan PKN, 1945

Oktifuadi, Khoirrosyid, 'No Title No Title', Journal of Chemical Information and Modeling, $\quad 53.9 \quad$ (2018), <https://doi.org/10.1017/CBO9781107415324.004>

Ramdhan, Tri Wahyudi. "Islam Nusantara: Pribumisasi Islam ala NU." Al-Insyiroh: Jurnal Studi Keislaman 2.1 (2018): 73-91.

Wahyono, Imron, 'Implementasi Nilai-Nilai Pancasila Dalam Kegiatan Pembelajaran Di Sdn 1 Sekarsuli the Implementation of Pancasila' S Values in Learning Activities in Sdn 1', 2018 